\title{
Research on the Teaching Situation and Reform Measures of Specialty English
}

\author{
Ling Jing \\ Jilin Jianzhu University \\ Changchun, China \\ jingling8082@126.com
}

\begin{abstract}
Specialty English is an important course for training practical ability and international standards of college students in the new period. However, the current Specialty English teaching effect is not ideal in colleges and Universities. This paper analyzes the Specialty English teaching situation and reasons of building environment and equipment engineering, through several years of English teaching and research, put forward five aspects measures to improve specialty English teaching effect: 1.Encourage students to see "light" English; 2. Modify training program combined with the actual situation; 3.Compile teaching materials as supplement. 4. Use a variety of teaching methods; 5 . Use bilingual teaching in curriculum.
\end{abstract}

Keywords- Research; Teaching Situation; Reform Measures; Specialty English

\section{INTRODUCTION}

Specialty English is the incorporation of English and expertise, its effect and status is increasingly prominent with increasing international intercourse and cooperation day by day. Specialty English course is from the standpoint of practice application, it is an important course that cultures new time undergraduate of strong practical ability and capability to be geared to international standards. The object of Specialty English is to make students to have the ability to exercise Basic English to Scientific English, enlarge vocabulary and grasp feature of Scientific English, thereby students could read specialized fields literature, periodical, be geared to international new expertise and grasp professional trend. Meanwhile, forge students to translate Chinese article abstract to English accurately and fluently. Whereas, effectiveness of Specialty English is not ideal at all in colleges and universities [1,2]. This paper analyzes teaching actuality and cause of Specialty English of Building Equipment and Environment Engineering, by teaching and probe for several years, put forward several educational reorganization measures.

\section{SPECIALTY ENGLISH TEACHING SitUATION AND REASONS OF BUILDING ENVIRONMENT AND EQUIPMENT ENGINEERING}

\section{A. The English Foundation of the Majority of Students Is Weak and Students Lack Confidence in English Learning.}

Building environment and equipment engineering specialty owing to science and engineering category, our school is the general undergraduate colleges and universities, so students do not have good basic skills of English, English foundation is weak. Enter third grade, the students have not pay attention to the study of English and professional teachers also not often emphasize the importance of specialty English, most students have no learning English. When re-exposed to English learning, students with more complex long sentence, difficult to understand sentences and long, rare professional vocabulary, so they lack of confidence in learning and have very strong psychological resistance.

\section{B. Training Program Has Defects.}

The specialty English course learning is on the foundation of university English course, in meanwhile, students have the stronger writing and translation ability, oral expression ability and reading ability, learning content is closely related with the professional knowledge and at the same time, students are required to have basic professional knowledge which is helpful to read and understand English text. Specialty English teaching involves numerous professional knowledge, such as Specialty English teaching content of building environment and equipment Engineering will involve "Engineering Thermodynamics", "Fluid Mechanics", "Heat Transfer”," Heating Engineering", "Air Conditioning" and a series of professional knowledge .It takes a long time to learn and consolidate If you want to through the English teaching to enable students to meet the teaching requirement. While most college English are arranged in the three grade and my school arrangement is in the fifth semester, a total of 32 hours, at that time the students just begin to contact the professional course and the professional knowledge has not form a system, it won't provides favorable conditions for specialty English learning [3]. So, no matter from the term arrangements or from hours to consider, there are some defects. Some professional English training programs of our school are shown in Tab. 1.

TABLE I. ENGLISH TRAINING PROGRAMS

\begin{tabular}{|c|c|c|}
\hline Specialty & Semester & Hours \\
\hline Power Engineering & 5 & 32 \\
\hline Computer Science & 5 & 32 \\
\hline Architecture & 7 & 40 \\
\hline Water Resources Engineering & 5 & 32 \\
\hline Engineering Management & 5 & 32 \\
\hline
\end{tabular}




\section{Learning Books Are Obscure and Lack Vividness.}

Optional textbooks of specialty English are rare, mainly uses some sections of the original books in foreign countries and related science books etc, the content is dull and the difficulty shades. The difficulty in learning specialty English is the comprehension of professional vocabulary and sentences in text, but there are no notes behind text, only listed vocabulary and options based on questions. Problems and options are obviously in pieces together. The use object of teaching material is college students, in the face of such learning books students have no interest, and even they want to study hard and they also do not know how to start. Without a close combination book of Basic English, professional knowledge and the actual situation of the students, it also increases the difficulty of explanation of teachers.

\section{Teaching Methods Are Single.}

The specialty English course teaching requires the combination of "English" and "specialty", and the characteristics of the course require professional teachers to act. At present young teachers of solid professional knowledge and good English foundation undertake specialty English teaching, but after all, they are not professional English teachers, literacy, oral English and grammar are not very strong which affects the teaching effect of vividness, flexibility, accuracy and teaching content in the depth, breadth. Specialty English course teaching is now basically as follows: the teacher first explains new words which are only limited to reading and translation, and then is text translation word by word. Some teachers first use Chinese to explain relevant professional knowledge to students and then translation the text. When the whole article has been translated the unit of learning is over. Limited to the English level and the grasp situation of students, the teacher rarely asked and there is no homework after class.

\section{E. The Teaching Results Can't Be Continued.}

After the end of professional English course in the fifth semester, students begin to contact the professional courses and curriculum design. But in the course of teaching process, there are basically no teachers use bilingual teachings and there are few teachers can refer to the corresponding English vocabulary when they explain common professional words. So, professional knowledge of English could not be continue to consolidate and deepen, students get credits also marking the professional English forever being irrelevant to themselves.

\section{F. Prevalence of Translation Software.}

The graduation design and thesis has the requirement of English abstract. When the Internet has not popularized, students can basically translate by themselves. But now the Internet is popular and there is much popular translation software, we hardly can see the students' own translation of English abstract in the thesis. Students with weak sense of responsibility will completely copy translate software content, teachers will find a lot of words list phenomena when check abstracts, which is inevitable defects of translation software. Students with good English foundation will review based on the software translation, but most translations are on the base of the software translation. Because of the translation software, students reduce the degree of emphasis on the professional English course [4,5].

\section{THE REFORM MEASURES OF SPECIALTY ENGLISH TEACHING}

\section{A. Encourage the Students to Look at the English as "Light".}

Teachers should first establish the confidence of learning English to students. To convey this information to the students: any language, including Chinese and English, said the ultimate of their functions or the highest significance, is nothing but the expression of feelings, transmission of information, communication and so on, is a kind of tool. Since we Chinese can handle very skillfully, English is the same, as long as we used to, say, write. Especially in learning English, because we've learned certain professional knowledge, then by virtue of professional foundation and the teacher's explanation, and the text of the association and understanding as well as auxiliary tools (dictionary, network) help, learning English is not difficult.

\section{B. Modify Training Program Combined with the Actual Situation.}

Theoretically speaking, English should be learning in university English and professional courses, they should be mutually, mutual penetration, together with training goal, namely to university English teaching is to provide a solid language foundation for professional English teaching, English teaching is the organic combination of professional knowledge and knowledge of English. But in the actual teaching there is obvious phenomenon of disjointed. Especially the more obvious defect is arranged in the professional English and professional course sequence. According to the present curriculum set in the fifth to the seventh semester, professional English courses should be arranged in the fifth semester.

The professional English course regardless of the original English teaching materials and textbooks, the length is longer, covering a wide range of knowledge and complex, if not including interludes of students in the teaching process of speech, on a unit usually takes 4 hours to complete, and want to get some teaching, learning is not only a few units. So the English the best arrangement in sixth semester, article seven two semesters, each semester should be 50-60 hours.

\section{Write Our Own Textbook as Supplement.}

Now science and technology development change rapidly, the original English teaching materials often several years are not updated, outdated contents, students without access to new knowledge, they have no interests. But the original edition of English in vocabulary and grammar are more accurately than the book we edited. So suggest that the original English teaching materials are as the foundation, the teacher according to the latest development of the professional dynamic to edit books as a supplement. The 
teaching content must be vivid and easy to understand. For example, teachers can collect the latest papers of the international meeting as teaching content.

Use a Variety of Teaching Methods to Enhance the Learning Interest. First of all, use multimedia as aided teaching mode. Get rid of old teacher sentence word for word translation teaching mode, the use of multimedia computer assisted instruction. For example, when go to the article 《Heating by Steam and High-pressure HOT Water》, do a simple heating system diagram by PPT and then explain equipments with English logo, with the animation process heating system, at the same time with English commentary. This will stimulate the visual system of the students, the level of understanding and memory will be more profound. You can also find some of the most professional new English original image data, in the classroom for students, so as to understand the expression of professional terminology, and to train the students' listening, develop the field of vision. This kind of teaching means, multimedia image vivid, intuitive, a large amount of information, the students by direct stimulation in the visual and auditory, can arouse the enthusiasm and allow them to be absorbed in into the learning state. This is also compensate for the specialized course teachers spoken language expression ability, improve students' listening ability, said a good way.

Secondly, change the students from passive to active. Students are always the protagonist in any course of study, the teacher only play a supporting role to answer doubts, the professional English should be so. In English teaching, should play a leading role in the students, to stimulate students' interest in learning. It involves building, energy and environment more and more international conferences and meetings, the use of language without exception is English, mode is basically the same, is the participants based on their paper made PPT speech. Professional English teaching can also imitate the form. Ask students to preview before class the learning content, to check the information of the professional content into PPT to lecture, the teacher and other students can ask questions speeches. This can practice oral English, but also can consolidate professional knowledge, the teacher in the teaching will be a lot easier, because the students after class before making PPT master professional many this lesson vocabulary and usage, the teacher can focus on.

Finally, send the young teachers to study abroad. The school should encourage and help young teachers to study the professional knowledge and English abroad, conditional school should hire the professional foreign teachers to assist English teaching or regular and professional English teachers. After several years of dispatch of learning, can cultivate a solid professional foundation, excellent young teachers of English, can form a good professional English teaching team, team of teachers can continue to train more young teachers.

\section{Use Bilingual Teaching in Professional Course.}

English is an important tool for the cultivation of comprehensive ability of students, the main task of teaching is to teach students how to master and use this tool. As mentioned before, if the professional English course in the sixth and seventh semester, professional foundation course in advance of professional English, and professional courses and professional English course. If teachers can refer to the corresponding English words in some common vocabulary about professional basic course, students will be early on professional English impression; at the same time, the teacher also penetrated English vocabulary and expressions when talking about the professional courses, it can consolidate the professional English. In this way, the professional English teaching results have continued to consolidate, very good use.

\section{E. Strengthen Daily Supervision and Inspection.}

Strictly require students to write English abstract in the course of design and research. Teachers should strictly, to strengthen this part of the examination.

\section{SUMMARY}

With the development of science and technology, the increase of international communication and globalization in education and elite education to mass education in this context, the importance of English will be more and more prominent. As a teacher, how to improve measures to make better teaching effects is our responsibility and challenge. All colleges and universities should fully mobilize the enthusiasm, initiative and responsibility of teachers. Teachers should use advanced teaching means and innovation, select teaching content reasonably to make the English teaching meet requirements.

\section{REFERENCES}

[1] Z.W. Wang,"Specialty English of Road Engineering," Vocational Education Research,Mar.2007, pp.85-86.

[2] R. J. Cao, J. W. Chen, D. Ye: "Some Experience in English Teaching,” The Science Education Article Collects Jan.2009, pp. 145-146.

[3] L. Zhang, L. Liu, "Research on Professional English of Science and Engineering University," West China Journal of Science and Technology Jan.2009, pp. 81-83.

[4] H.J.Chang, G.D.Lu, Y.T.Xian,"Discussion of Specialized English Teaching Method," The Science Education Article Collects, Dec.2008, pp.135

[5] Z.X.Gao,"Teaching Present Situation and Countermeasure Analysis of Civil Eineering Pofessional English,”Journal of jilin Rdio and TV university ,Feb.2009, pp.85-87. 